\title{
AC 2007-1484: MEASURING STUDENT LEARNING AND ENGAGEMENT IN AN INTRODUCTORY ELECTRICAL SCIENCE COURSE
}

Haley Haywood, Oklahoma State University

Forrest Austin, Oklahoma State University

Seth Williams, Oklahoma State University

Cameron Musgrove, Oklahoma State University

Charles Bunting, Oklahoma State University 


\title{
Measuring Student Learning and Engagement in an Introductory Electrical Science Course
}

\begin{abstract}
Does encouraging student development through projects increase engagement in a course? Can we use student performance on case studies to measure learning? These questions arose in discussions among faculty and teaching assistants in the Introduction to Electrical Science course at Oklahoma State University who perceived student engagement is less when students do not apply the skills learned in the course.

The School of Electrical and Computer Engineering at Oklahoma State University (OSU) is redesigning courses to improve student learning under a National Science Foundation (NSF) Department Level Reform project- Engineering Students for the $21^{\text {st }}$ Century (ES21C). This project seeks to develop higher levels of learning by matching course work to objectives using Bloom's Taxonomy. The introductory electrical science course is being reformed to increase students' ability to analyze and apply knowledge by incorporating new problem-based and active learning techniques into the course. These techniques include individual web-based pre-lecture assignments, team projects, individual and group quizzes, in-class laboratory exercises presented as case studies, and combined traditional and case analysis exams. Ideally, students will be more engaged in the course and increase their depth of knowledge.

In this paper we examine changes made to the course and what we hope to measure through these changes. A preliminary Student Assessment of Learning Gains (SALG) survey along with an attitude questionnaire (created by undergraduates working on the NSF project ES21C) was given to students enrolled in the introductory electrical science course before changes were made.
\end{abstract}

\section{Introduction}

Students graduating from OSU's School of Electrical and Computer Engineering (ECEN) may have a wealth of knowledge after completing their required courses, but will graduates have developed the skills needed to be an engineer? To create a more effective, engaged, and efficient curriculum, the ECEN department is implementing program change from a primarily knowledgebased paradigm (acquiring a set of concepts) to being development-based (emphasizing students' development). In a development-based program faculty redefine their roles from lecturers to mentors and scholars, guiding academic development towards complex problem solving tied to real world problems. Six of OSU's ECEN faculty have come together to adapt active learning methods to ten strategic courses within the curriculum. Classes will teach students the process of solving the problems in addition to the concepts needed to understand them. Under a National Science Foundation Department Level Reform grant- Engineering Students for the $21^{\text {st }}$ Century $^{1}$ (ES21C), ECEN faculty hired seventeen undergraduates to aid in course development by developing course materials, measurement instruments, and equipment for projects. By using undergraduate researchers to assist in course reform interested faculty hope to provide meaningful course experiences to the students. ES21C hopes to demonstrate increased student engagement and real world preparation through classes centered on student development. 
Possibly one of the most challenging courses to adapt due to its large size and multidisciplinary nature is ENSC 2613 Introduction to Electrical Science. Although this course is the basis to many electrical engineering courses, it is also multidisciplinary (including but not limited to mechanical, civil, industrial, and chemical engineers), and is also populated by over one hundred students in both fall and spring.

The development model used in this paper is based on Bloom's Taxonomy ${ }^{2}$, a model of learner development which identifies six levels of learning and helps faculty know when students have mastered a level. A simplified version of this model is shown in Figure 1.

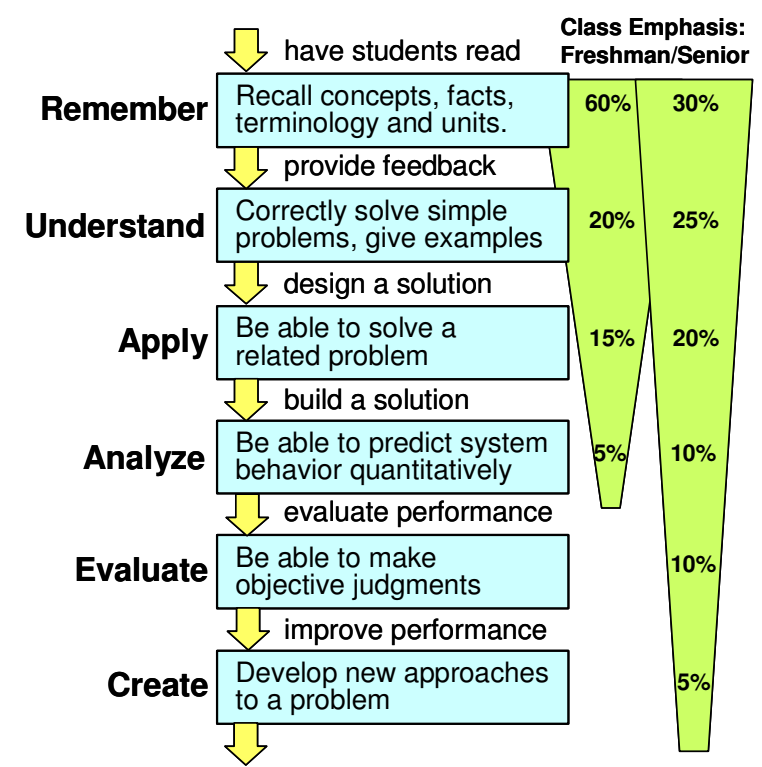

Figure 1: Bloom's Taxonomy used as a developmental model to identify and develop deep levels of thinking in students.

Levels of learning are represented by shaded boxes; the name of each level is at the left. Shallow levels of learning are at the top while deep levels are at the bottom. The model is hierarchical- to reach deep levels of understanding it is necessary to first master shallow levels. In other words, remembering concepts is needed to understand them, and understanding concepts is a prerequisite for applying them. Each level represents increasing ability to solve problems. Arrows represent students' progress to deeper levels of learning. Example tasks that students might undertake that develop the skills needed to advance to deeper levels are listed at the right of the arrows. Courses during the freshman and sophomore years emphasize the lower levels, while upper division courses place more emphasis on higher levels. This distribution of emphasis is represented at the right of each block by depicting how course work that is devoted to each level might be distributed in a freshman course and a senior course.

Two key elements of the ES21C model that are implemented in ENSC 2613 are:

(1) Questions, technologies, and problems are posed to students through a case study to make the problem relevant to students and emphasize the social, ethical, and economic impact. 
(2) The students are walked through the process of solving the problem posed in the case study in three steps:

(2a) Use teaching techniques that help each student individually remember and understand concepts needed in solving the problem outside of the classroom.

(2b) Maximize the time faculty are able to actively interact with students by using time in-class to let student teams apply what they know in analyzing the problem under faculty and TA guidance.

(2c) Support student teams as they first design a solution to the problem, then implement that solution in the laboratory/class by using the tools and techniques employed by practicing engineers. Faculty help students create a method of solution and evaluate their understanding.

The developmental model implemented in ES21C is a model designed to exercise deeper levels of thinking, specifically the: apply and analyze levels of Blooms Taxonomy ${ }^{2}$. Real world application of class concepts are exposed through class projects connected with case studies. Professional engineers work on teams to complete a task; therefore students in ENSC 2613 were assigned teams to complete the assigned case study and project.

Due to the significant challenges associated with modifying a class this large with students of various disciplines and learning styles as well as to better evaluate the impact of these new techniques on the class, an ABA research design was employed. ENSC 2613 retained most of its traditional techniques, during Module A, and added a development-based section between the first and second midterm exams. This new development-based segment, referred to as Module B, was created by a joint effort of an experienced professor and a team of undergraduate and graduate students researching the developmental model and its classroom implementation. Module B encompassed a section of an entirely development-based methodology to be compared with the lecture-based "traditional" approach.

The following section explains the course structure before the experimental phase conducted during the fall of 2006. It essentially describes the methodology (called "traditional" in this paper) of Module A. Student attitudes toward course elements are presented. Section III presents the approach to Module B - the case study development and its elements. The new course outline as administered in spring of 2007 in Section IV and conclusions follow in Section V.

\section{Fall 2006 ENSC 2613 at Oklahoma State University: Specific rationale for change}

\section{Course Structure}

The fall 2006 semester was the fourth semester with a traditional lecture-based structure under the same instructor. The course week consisted of a three day lecture and weekly homework assignment. Class assignments consisted of 9-10 homework problems from the course text. The instructor did engage in occasional and irregular in-class quizzes. The quizzes were short (10 to 15 minutes), with typical problems of lesser difficulty than homework problems. Students were asked to work problems individually for 5 minutes, and then complete the quiz in collaborative and informal teams for the remaining 5 to 10 minutes. The quizzes initiated student discussion of course topics. By keeping teams small (usually two people), each student was engaged. 
In general, students seemed satisfied with this course structure. At the end of the fall 2006 semester, 90 out of 130 students completed a Student Assessment of Learning Gains (SALG) along with a brief attitude questionnaire written by undergraduates working on the ES21C program.

\section{SALG results}

This section highlights student responses from the given SALG. The SALG survey questions are listed in Appendix A. When analyzing the SALG data, we highlight three questions below to examine the fall 2006 students.

\section{What Do Students Prefer?}

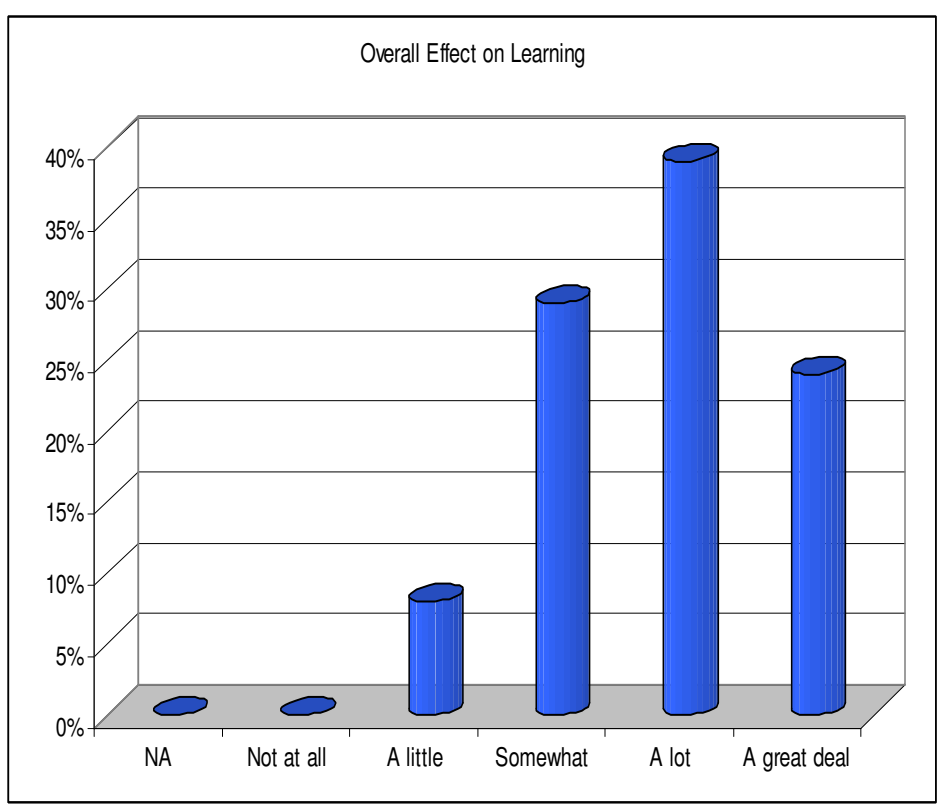

Figure 2. Fall 2006 SALG results taken from question 1(K) How much did [the way this class was taught overall] help your learning?

Since the fall 2006 course was lecture-based, the results of Figure 2 show that students seem to like the traditional course. Two explanations for high lecture approval are familiarity of lecturebased courses among college students and high instructor approval ratings. This suggests more than half the students from the fall 2006 semester were satisfied with the course as it was. However, discussion and group work preferences were still highly valued by students as $64 \%$ of the test subjects feel as if group activities encourage their effort to learn and only $4 \%$ have a negative feeling towards it (data not presented in figure form). These results influenced our new course structure. Rather than remove all lecture material, we simply added group discussion material to aid in learning rather than remove a key instructional technique. 


\section{What Does the "Traditional" Approach Do For Students?}

Based on the results in Figure 3 taken from question 4(A), a majority of students feel they understand main concepts. A problem with students self reporting a "good" understanding of the material is that we do not have a way to measure student understanding other than performance on tests or quizzes in a traditional approach to instruction.

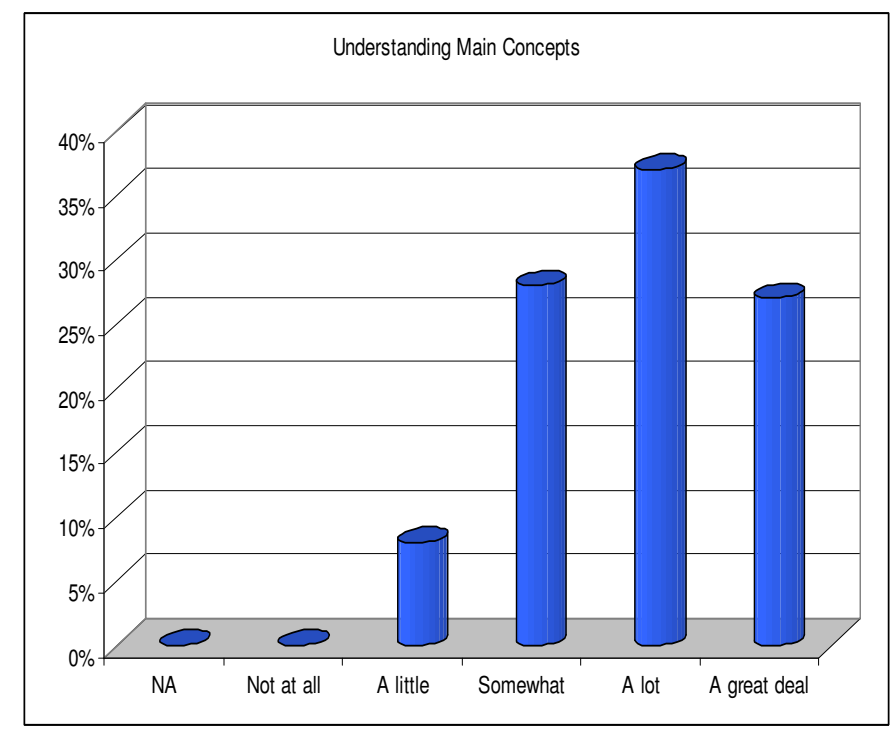

Figure 3. Fall 2006 SALG results taken from question 4(A). To what extent did you make gains in [understanding main concepts] as a result of what you did in this class?

Students are comfortable with ENSC 2613. College courses are traditionally lecture based, unless the course is designated as a lab course, so why change it? One reason arguing for change is the lack of a hands-on component in the course. Students may have difficulty accepting that these circuit elements have any reality if they never hold components, construct simple circuits, and test them. How can they be expected to understand how electrical systems behave in a lab or commercial environment without any exposure? Students may claim to understand concepts, but may not be able to apply the concepts. As a result, we created case studies in hopes of using student performance to rate student understanding when applying their knowledge.

\section{Are We Encouraging Student Development?}

Although we like students to enjoy the classes they take, our primary focus is to help students develop their engineering skills and understand real world applications. Figure 4 shows only half the students see relevance in ENSC2613. 


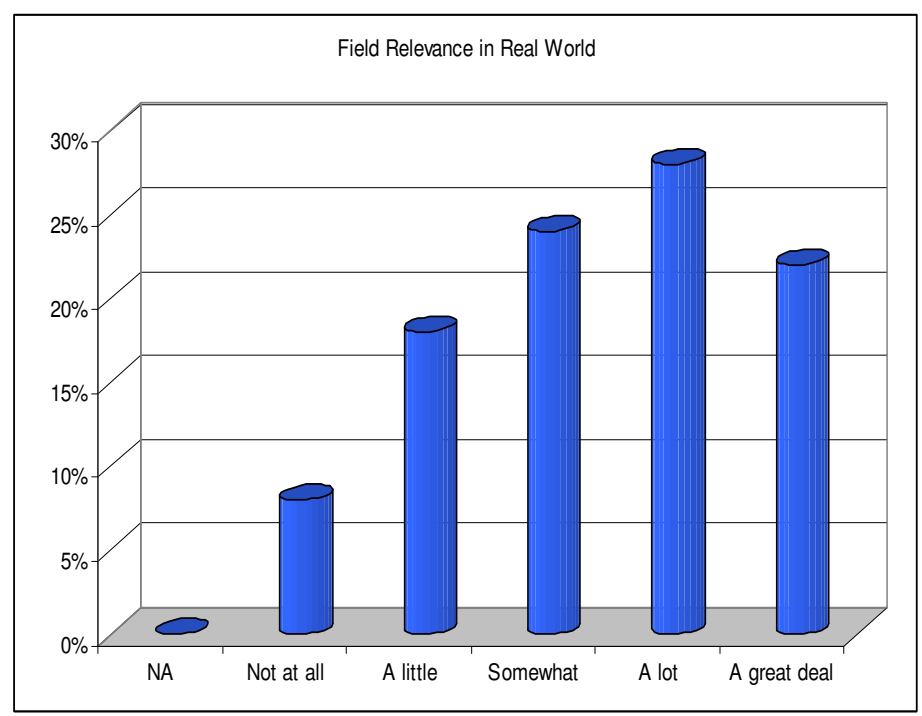

Figure 4. Fall 2006 SALG results taken from question 4(C)

To what extent did you make gains in [material relevant to the electrical engineering field] as a result of what you did in this class?

Case studies introduced field examples to students taking the course in spring 2007. If case analysis proves helpful to students in the new semester, more case studies can be introduced to coincide with the course lectures. If students are able to see application of core material, it may motivate student learning and engagement.

\section{Attitude Survey}

One challenge associated with ENSC 2613 is illustrating the benefit of understanding basic electrical engineering to every engineering discipline required to take it. The electrical engineers are generally easy to please. When asked, "Is this course useful to you", the following response summarized the EE responses.

"[My major is Electrical Engineering. ENSC 2613] applies to everything that I may do at one point or another. This course is the basis for everything that I will learn and do in the years to come."

However students from other engineering disciplines such as Mechanical and Chemical Engineers believed ENSC 2613 was completely useless to them. It is hoped that the case study project introduced will help students find an interest in the class, or relate the class work to their major. Some of the mechanical engineering students are unaware that following later in their coursework they will use many of the concepts in ENSC 2613.

From a Mechanical Engineering student:

"There are no applications of this course to my field of study. I'm disappointed that some tenured professor convinced the dean that his class was vital to my educational experience. I am aware that this material is covered on the FE, but I do not anticipate using it again."

From a Chemical Engineering student: 
"I don't know of any applications of this course in my field."

Other students were able to see some point to taking the course but these ranged from preparation for the Fundamentals of Engineering Examination (FE) to seeing how some knowledge of the basics of electrical engineering might be useful.

"My major is mechanical engineering and circuits are involved in almost every mechanical process."

"My major is civil engineering and I am sure that there are applications of this course in my field, but they don't play a very big role. “

"I am a mechanical engineer and therefore most likely won't use this in the field. But I do feel it is important for a mechanical engineer to be able to understand all aspects of a system somewhat. And this class does a pretty good job to introducing someone to simple circuit analysis."

"As a civil engineer, this course prepared me for the electrical portion of the FE."

Students were also asked what they would change about this course. Most responses suggested leaving the course as is. Some responses suggested group work.

"I thought that the lecture was one of the best that I have had. I like the step by step way in which example problems were done. I also liked the way quizzes were carried out. I felt that the homework was adequate. I like group material, but I think what we had was good"

"If anything I would choose to have more group material. I sometimes learn better when there is more than just my brain involved."

"I like classes like this to have a discussion section where I can ask questions."

\section{Case Studies and Development-Based Learning - Module B}

Many schools in the United States are researching curriculum reform and innovative teaching methods to improve the quality of education and increase scientific literacy. Researchers have found a promising method of instruction that engages students in learning. Students are more engaged when learning from true narratives, especially those including ethical and social problems related to their discipline ${ }^{3}$. We have referred to these narratives as case studies.

A case study is a real life application or problem brought into the classroom. These problems can be created by instructors or taken from real-life examples. Case studies in classrooms promote discussion and impact student learning when thought through and solved by the students. A case study should require students to have a deeper and more developed understanding of course content. For example, a case study cannot be a simple "plug and chug" math problem. A case study should give students experience in analyzing a problem and using 
their knowledge from the course to solve the problem. The ENSC 2613 case studies not only give students experience with problem solving on paper, but also require students to build and test prototypes, giving students hands on experience and immediate feedback on their understanding of course material.

Mary Lundeberg ${ }^{3}$ suggests the use of additional methods other than student performance to assess student learning. These methods include interviews, journal entries, observations, and case studies of particular students to measure student learning and engagement. "Such methods would allow us to access students' cognition and understanding of science concepts, and to understand more about how and why cases affect student understanding in science."

Students were given case-like elements during each test and the final exam. The student responses were coded and a rubric devised to analyze the nature of student learning under each module. In addition, ENSC 2613 students were given a modified Student Assessment of Learning Gains (SALG) survey upon completion of the spring 2007 semester. A unique opportunity within the ES21C structure is that a doctoral student is available from OSU's College of Education to assist in the reform process. During the spring of 2007, ENSC 2613 this doctoral student observed class activity and behavior during lecture-based instruction (Module A), case study, and development-based instruction (Module B). This doctoral student, as a trained observer, contributed significantly to the process of course reform in providing immediate feedback as to what was "working" and what was not.

An example of a case study is provided below. This particular case study was distributed to the class to introduce their out-of-class project to construct an operational amplifier based temperature converter. To help students relate to the problem, the case story characters were a team of young engineers that were sent an email by their supervisor to complete the task of converting a Celsius temperature to a Fahrenheit temperature. The young engineers discussed approaches to completing the project that students used to guide their own solution to the problem. The deliverable from the students was an evaluation of the temperature conversion accuracy of their circuit compared against the conversion equation. By asking them to evaluate their project in terms of the converted values, how the students chose to implement their design is not relevant to their final grade (there was more than one correct answer). Thereby, each team had the freedom to explore and discuss between themselves the differences between design alternatives. When students discussed these alternatives, providing information to support or disprove an alternative provoked a dialog within (and between) groups to enhance their collective understanding of the material. Many professors will attribute their own deep knowledge of a subject to teaching the material. If students are 'teaching' material to each other, more students will understand and learn the material. Also, the case study can answer the ageold school question, "When are we ever going to use this?" 
"Hey guys, did you see this email from the Boss?" Dave did look away from his screen. The other three created a sound of clicking fury in the cubical area as they checked their email in unison. The email read as follows:

To: Axle, Dave, Jeff, and Catalina

From: Bob Caudillo

Subject: New Project

I got this one handed down from above; we have a problem. Our consumer electronics division just received 1 million temperature sensors for our company's new digital thermometers that display degrees Celsius! You need to find a way to modify these temperature sensors to output Fahrenheit.

Bob Caudillo

Saved by the Bell, Inc.

Lead Engineer

M/S: GG75

(702) $555-5555$

"Hey, I did this once before in school," said Axle, "There is an equation to convert between Celsius and Fahrenheit. I'm going to Google it."

"But how is that going to help us? Can we program something to use the equation?" asked Jeff.

Catalina countered, "We don't have to program anything. Cascaded op amps will implement many different kinds of equations."

"Ah-ha!" exclaimed Axle. Everyone briefly looked surprised at Axle for his sudden outburst, even though Axle frequently has sudden outbursts. "Ya, the conversion equation is $\mathrm{a}$ ' $\mathrm{mx}+\mathrm{b}$ ' equation. Easy to do."

"So, an op amp and a few resistors on the LCD board should not take up that much space..." mused Dave.

"The integration people are going to be really upset if we have to change board dimensions, so we better be sure exactly how much space we need," cautioned Jeff.

Dave collected his thoughts, "For now, let's concentrate on getting the gain op amp working. Jeff and Catalina, why don't you gather the parts to build a prototype, and get started on construction. Axle and I will design the circuit. We'll have exact resistor values for you shortly." 


\section{Spring 2007 ENSC 2613 at Oklahoma State University-ABA Research Design}

\section{Class Structure}

In the spring session of ENSC 2613 the course had a four week intersession (Module B). This section of the course covered the topic of electrical measurements, operational amplifiers, and $\mathrm{RC}$ and RL transients followed by the second midterm exam. Immediately following the second exam, the students returned to Module A for the remainder of the semester. A brief outline is illustrated below.

\begin{tabular}{|c|c|c|}
\hline \multicolumn{3}{|c|}{ Table 1. Spring 2007 A-B-A Class Outline } \\
\hline Semester Weeks & Course Style & Topics \\
\hline $1-5$ & $\begin{array}{c}\text { Traditional Lecture Based } \\
\text { Module A }\end{array}$ & $\begin{array}{c}\text { Basics, KVL, KCL, Ohm's Law, } \\
\text { nodal and mesh analysis, Thevenin } \\
\text { and max power transfer }\end{array}$ \\
\hline $6-9$ & $\begin{array}{c}\text { Development Based } \\
\text { Module B }\end{array}$ & $\begin{array}{c}\text { Measurement of voltage and current, } \\
\text { operational amplifiers, RC and RL } \\
\text { transients }\end{array}$ \\
\hline $10-16$ & $\begin{array}{c}\text { Traditional Lecture Based } \\
\text { Module A }\end{array}$ & $\begin{array}{c}\text { Sinusoidal analysis (phasors), } \\
\text { impedance, resonance, filters, AC } \\
\text { Power, max power, power factor } \\
\text { correction }\end{array}$ \\
\hline
\end{tabular}

Regular days:

Prior to each lecture period the students were given an online quiz (a total of 10 in spring 2007) asking questions over the material to cover basic principles. These questions concentrated on the lower levels of Bloom's taxonomy of remember and understand and asked only the most basic calculations and theory. The students were expected to be able to move through the on-line quiz from reading the text alone. The professor was able to view the results from the activities and then provide a mini-lecture on the concepts that the students seem to have the most trouble conceptualizing. In-class quizzes addressed the next levels of Bloom's taxonomy of apply and analyze. These quizzes were executed individually (timed: 10 minutes) and then as a team (timed: 10 minutes) and were typically unsolvable by an individual in the allotted time.

Hands-on days:

On the first Friday of Module B, a basic measurement of voltage and current exercise was given. This hands-on exercise was designed to familiarize the students with the breadboard, resistors (and the resistor color code), the digital multimeter, basic resistor layouts, and the procedures associated with measuring voltage (a parallel connection) and current (requiring them to "break" circuit connections and replacing the connection with the meter). The second Friday assignment required students to construct an operational amplifier and take various data from it. This helped students familiarize themselves with building an operational amplifier circuit. The students were asked to calculate and then verify their work with measurement tools. This not only forced students to review course topics, but also gave them experience with standard measuring equipment used in the electrical engineering field.

On the second Friday of Module B the students were given a two week case study that required them role play as part of a company to design a temperature converter. Students were asked to 
build a circuit that converts Celsius to Fahrenheit using an Operational Amplifier and a LM35 temperature sensor chip. Given a small list of supplies the teams of students were required to use their collective knowledge of course material and problem solving abilities to determine a configuration of resistors that will allow for the conversion. At the end of module $\mathrm{B}$, teams submitted a brief report showing their design process as well as the design prototype testing results.

Individual homework assignments were required to maintain the emphasis on individual accountability throughout Module B.

\section{Summary}

The primary focus of the Engineering Students for the $21^{\text {st }}$ Century project is to create a course structured to encourage engineering student development. To minimize the potential for creating a difficult learning environment due to the multidisciplinary demographics and sheer class size we have created a course composed of two modules. Module A, a traditional lecture-based course with modified informal group quizzes and homework assignments; and module $\mathrm{B}$, an innovative structure developed from problem based learning and active learning techniques. By presenting this material in the $\mathrm{ABA}$ research design, we hope to be able to compare student learning and engagement levels from both teaching styles. The ABA research design also gives students from the spring 2007 semester the option to criticize both modules of learning, ideally giving feedback to the electrical engineering faculty and student researchers to be used in future semesters to improve the implementation. Based on positive feedback from module $\mathrm{B}$, future offerings of the class will adopt an $\mathrm{ABAB}$ research design. Based on current feedback from students, the Module A format is expected by the class to be the preferred method of instruction and it is anticipated that openness to change will be slow.

\section{Acknowledgement}

The authors acknowledge support from the National Science Foundation through award NSF0530588. Ms. Haywood, Mr. Austin, and Mr. Williams would like to acknowledge support from a National Science Foundation REU award (NSF0631565) which enabled them to conduct the research presented in this paper. Any opinions, findings and conclusions, or recommendations expressed in this material are those of the authors and do not necessarily reflect the views of the National Science Foundation.

\section{Bibliography}

1. D. R. Krathwohl, "A revision of Bloom's Taxonomy: An Overview," Theory into Practice, vol. 41, pp. 212-218, 2002.

2. Engineering Students for the $21^{\text {st }}$ Century Web site, http://es 21 c.okstate.edu/

3. Lundeberg, M. A. \& Yadav, A. Assessment of case study teaching: Where do we go from here? Part 1 Journal of College Science Teaching, vol. 35 (5), pp. 10-13, 2006 
Appendix A - SALG Survey

Student Assessment of Learning Gains

\begin{tabular}{|c|c|c|c|c|c|c|}
\hline \multicolumn{7}{|c|}{$\begin{array}{l}\text { Instructions: } \\
\begin{array}{l}\text { Check one value for each question on each scale. If the question is not applicable, check 'NA'. You may add } \\
\text { a comment for any item in the text box at the end of the survey. }\end{array}\end{array}$} \\
\hline \multicolumn{7}{|c|}{ Q1: How much did each of the following aspects of the class help your learning? } \\
\hline & NA & No help & $\begin{array}{l}\text { A little } \\
\text { help }\end{array}$ & $\begin{array}{l}\text { Moderate } \\
\text { help }\end{array}$ & $\begin{array}{c}\text { Much } \\
\text { help }\end{array}$ & $\begin{array}{c}\text { Very much } \\
\text { help }\end{array}$ \\
\hline $\begin{array}{l}\text { A. The way in which the material was } \\
\text { approached }\end{array}$ & C & C & C & C & $\mathbf{E}$ & $\mathbf{C}$ \\
\hline $\begin{array}{l}\text { B. How the class activities, labs, reading, and } \\
\text { assignments fit together }\end{array}$ & $\mathrm{C}$ & $\mathrm{C}$ & C & $\mathbf{C}$ & $\mathbf{C}$ & C \\
\hline C. The pace at which we worked & $\mathrm{C}$ & $\mathbf{C}$ & C & C & $\mathbb{C}$ & C \\
\hline D. The class activities & NA & No help & $\begin{array}{c}\text { A little } \\
\text { help }\end{array}$ & $\begin{array}{c}\begin{array}{c}\text { Moderate } \\
\text { help }\end{array} \\
\end{array}$ & $\begin{array}{c}\text { Much } \\
\text { help }\end{array}$ & \begin{tabular}{|c|}
$\begin{array}{c}\text { Very much } \\
\text { help }\end{array}$ \\
\end{tabular} \\
\hline 1. Class presentations (including lectures) & $\mathrm{C}$ & C & C & C & $\mathbb{C}$ & C \\
\hline 2. Discussion in class & $\mathrm{C}$ & C & C & C & C & C \\
\hline 3. Group work in class & C & C & C & C & C & C \\
\hline E. Tests, graded activities and assignments & NA & No help & $\begin{array}{l}\text { A little } \\
\text { help }\end{array}$ & $\begin{array}{l}\text { Moderate } \\
\text { help }\end{array}$ & $\begin{array}{c}\text { Much } \\
\text { help }\end{array}$ & $\begin{array}{c}\text { Very much } \\
\text { help }\end{array}$ \\
\hline 1. Opportunities for in-class review & C & C & C & C & C & C \\
\hline 2. The number and spacing of tests & $\mathrm{C}$ & C & C & C & C & C \\
\hline 3. The fairness of test content & $\mathrm{C}$ & C & C & C & C & C \\
\hline 4. The mental stretch required of us & $\mathrm{C}$ & $\mathrm{C}$ & C & C & C & C \\
\hline 5. The grading system used & $\mathrm{C}$ & C & C & C & $\mathbb{C}$ & C \\
\hline 6. The feedback we received & C & C & C & C & $\mathbb{C}$ & C \\
\hline F. Resources & NA & No help & $\begin{array}{l}\text { A little } \\
\text { help }\end{array}$ & $\begin{array}{l}\text { Moderate } \\
\text { help }\end{array}$ & $\begin{array}{c}\text { Much } \\
\text { help }\end{array}$ & $\begin{array}{c}\text { Very much } \\
\text { help }\end{array}$ \\
\hline 1. The text & $\mathrm{C}$ & C & C & C & $\mathbf{C}$ & C \\
\hline 2. Other reading materials & C & $\vec{C}$ & C & C & C & C \\
\hline 3. Use made of the WWW in this class & $\mathrm{C}$ & C & C & C & C & C \\
\hline G. The information we were given about & NA & No help & $\begin{array}{c}\text { A little } \\
\text { help }\end{array}$ & $\begin{array}{c}\begin{array}{c}\text { Moderate } \\
\text { help }\end{array} \\
\end{array}$ & $\begin{array}{c}\text { Much } \\
\text { help }\end{array}$ & \begin{tabular}{|c|}
$\begin{array}{c}\text { Very much } \\
\text { help }\end{array}$ \\
\end{tabular} \\
\hline 1. Class activities for each week & $\mathrm{C}$ & C & C & C & C & C \\
\hline $\begin{array}{l}\text { 2. How parts of the classwork, labs, reading, or } \\
\text { assignments related to each other }\end{array}$ & $\mathrm{C}$ & $\mathbf{C}$ & C & C & $\square$ & $\mathrm{C}$ \\
\hline
\end{tabular}




\begin{tabular}{|c|c|c|c|c|c|c|}
\hline 3. The grading system for the class & $\mathrm{C}$ & $\bar{C}$ & C & C & $\bar{E}$ & C \\
\hline H. Individual support as a learner & NA & No help & $\begin{array}{l}\text { A little } \\
\text { help }\end{array}$ & $\begin{array}{l}\text { Moderate } \\
\text { help }\end{array}$ & $\begin{array}{c}\text { Much } \\
\text { help }\end{array}$ & $\begin{array}{l}\text { Very much } \\
\text { help }\end{array}$ \\
\hline 1. The quality of contact with the teacher & $\mathrm{C}$ & C & C & C & C & C \\
\hline 2. The quality of contact with the TAs & C & C & C & C & $\square$ & C \\
\hline 3. Working with peers outside of class & $\mathrm{C}$ & C & C & C & C & C \\
\hline K. The way this class was taught overall & $\mathrm{C}$ & C & C & C & C & C \\
\hline \multicolumn{7}{|c|}{$\begin{array}{l}\text { Q2: As a result of your work in this class, how well do you think that you now understand } \\
\text { each of the following? }\end{array}$} \\
\hline & NA & $\begin{array}{c}\text { Not at } \\
\text { all }\end{array}$ & A little & Somewhat & A lot & $\begin{array}{c}\text { A great } \\
\text { deal }\end{array}$ \\
\hline 1. Using Ohm's Law & $\mathrm{C}$ & C & C & $\mathbf{C}$ & C & C \\
\hline $\begin{array}{l}\text { 2. Applying Kirchoff's Current and Voltage } \\
\text { Laws }\end{array}$ & C & $\mathbf{C}$ & C & $\mathbb{E}$ & $\mathbf{C}$ & C \\
\hline 3. Analyzing Resistor Networks & $\mathrm{C}$ & C & C & C & $\mathbb{C}$ & C \\
\hline $\begin{array}{l}\text { 4. Applying Node Voltage and Mesh Current } \\
\text { Methods }\end{array}$ & $\mathrm{C}$ & $\mathbf{C}$ & $\mathbf{C}$ & $\mathbf{C}$ & $\mathbf{C}$ & $\mathbf{C}$ \\
\hline $\begin{array}{l}\text { 5. Calculating Maximum Power delivered to an } \\
\text { appropriate load }\end{array}$ & $\mathrm{C}$ & $\mathbb{C}$ & C & $\mathrm{C}$ & $\mathbb{C}$ & C \\
\hline 6. Analyzing an Ideal Op Amp circuit & C & C & C & C & $\mathrm{C}$ & C \\
\hline 7. Analyzing L and C Networks & $\mathrm{C}$ & C & C & C & C & C \\
\hline $\begin{array}{l}\text { 8. Analyzing natural and step Response of RC } \\
\text { and RL Circuits }\end{array}$ & $\mathbf{C}$ & $\mathbf{C}$ & $\mathbf{C}$ & $\mathbf{C}$ & $\mathbf{C}$ & $\mathbf{C}$ \\
\hline $\begin{array}{l}\text { 9. Calculating the impedance for various circuit } \\
\text { elements and configurations }\end{array}$ & C & $\mathbb{C}$ & C & C & $\square$ & $\mathbb{C}$ \\
\hline 10. Calculating complex power & C & C & $\mathbf{C}$ & C & $\square$ & C \\
\hline $\begin{array}{l}\text { 11. Utilizing complex numbers in circuit } \\
\text { analysis techniques }\end{array}$ & C & $\mathbf{C}$ & C & C & $\mathbb{E}$ & $\mathrm{C}$ \\
\hline 12. Making power factor corrections & C & C & C & C & C & C \\
\hline \multicolumn{7}{|c|}{ Q3: How much has this class added to your skills in each of the following? } \\
\hline & NA & Nothing & A little & Somewhat & A lot & $\begin{array}{l}\text { A great } \\
\text { deal }\end{array}$ \\
\hline 1. Solving problems & $\mathrm{C}$ & $\mathbf{C}$ & $\mathbf{C}$ & $\mathbf{C}$ & $\mathbb{C}$ & C \\
\hline 2. Writing papers & C & $\mathbb{C}$ & C & C & C & C \\
\hline 3. Designing lab experiments & C & C & C & C & $\mathbf{C}$ & C \\
\hline 4. Finding trends in data & $\mathrm{C}$ & C & C & C & C & C \\
\hline
\end{tabular}




\begin{tabular}{|c|c|c|c|c|c|c|}
\hline 5. Critically reviewing articles & $\mathrm{C}$ & C & C & C & $\mathbb{C}$ & C \\
\hline 6. Working effectively with others & $\mathrm{C}$ & C & C & C & C & $\mathbf{C}$ \\
\hline 7. Giving oral presentations & C & C & C & C & $\mathrm{C}$ & C \\
\hline \multicolumn{7}{|c|}{$\begin{array}{l}\text { Q4: To what extent did you make gains in any of the following as a result of what you dic } \\
\text { in this class? }\end{array}$} \\
\hline & NA & $\begin{array}{c}\text { Not at } \\
\text { all }\end{array}$ & A little & Somewhat & A lot & $\begin{array}{c}\text { A great } \\
\text { deal }\end{array}$ \\
\hline 1. Understanding the main concepts & C & C & C & C & C & C \\
\hline $\begin{array}{l}\text { 2. Understanding the relationship between } \\
\text { concepts }\end{array}$ & $\mathrm{C}$ & C & C & C & $\boldsymbol{C}$ & C \\
\hline $\begin{array}{l}\text { 3. Understanding how ideas in this class relate } \\
\text { to those in other science classes }\end{array}$ & C & $\mathbf{C}$ & $\mathbf{C}$ & C & $\mathbf{C}$ & C \\
\hline $\begin{array}{l}\text { 4. Understanding the relevance of this field to } \\
\text { real world issues }\end{array}$ & C & $\mathbf{C}$ & $\boldsymbol{C}$ & C & $\mathbf{C}$ & C \\
\hline 5. Appreciating this field & C & C & C & C & $\mathrm{C}$ & C \\
\hline $\begin{array}{l}\text { 6. Ability to think through a problem or } \\
\text { argument }\end{array}$ & $\mathrm{C}$ & $\mathbf{C}$ & $\mathbf{C}$ & $\mathbf{C}$ & $\mathrm{C}$ & $\mathbf{C}$ \\
\hline 7. Confidence in your ability to do this field & C & C & C & C & $\mathbb{C}$ & C \\
\hline 8. Feeling comfortable with complex ideas & C & C & C & C & C & $\mathbb{C}$ \\
\hline 9. Enthusiasm for subject & C & C & C & C & $\mathrm{C}$ & $\mathrm{C}$ \\
\hline \multicolumn{7}{|c|}{$\begin{array}{l}\text { Q5: How much of the following do you think you will remember and carry with you into } \\
\text { other classes or aspects of your life? }\end{array}$} \\
\hline & NA & $\begin{array}{c}\text { Not at } \\
\text { all }\end{array}$ & A little & Somewhat & A lot & $\begin{array}{l}\text { A great } \\
\text { deal }\end{array}$ \\
\hline 1. Understanding the main concepts & C & C & C & C & $\mathrm{C}$ & $\mathbb{C}$ \\
\hline \multicolumn{7}{|c|}{ Q6: Add comments below } \\
\hline $11 \square$ & & & & 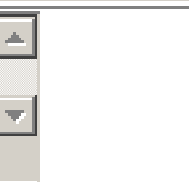 & & \\
\hline
\end{tabular}

